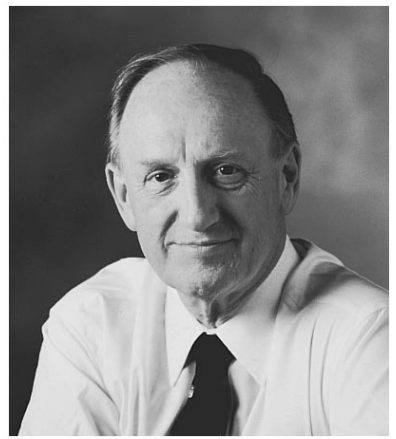

\section{Anniversaries, Nostalgia, and the Future}

Just a few days before writing this editorial I spoke to a group at the University of Rochester as they began the process of planning for the sesquicentennial of our institution. It is certainly interesting to think about the changes in the university over the 150 years since its founding in 1850. (Of course I have intimate knowledge for only $20 \%$ of that time.) One of the group asked the question "who owns the university?" After a moment's thought my answer was "future generations of students." The role of the faculty and staff is to provide the best possible education for those students, and the trustees have the responsibility of making sure that the institution moves into the future with the human resources, the physical plant, and the financial strength to fulfill the university's mission: to educate future generations of students.

It seems that we all reach that point in life when being involved in anniversary celebrations becomes an unavoidable duty! Thus over the very recent past I have been involved with the 80th anniversary of the Center for Governmental Research (an independent, not-for-profit organization here in Rochester, of which I am currently the chair of the Board of Trustees), I had the honor to chair the 40th Anniversary Meeting of SPIE in San Diego in 1995 , and I was involved with the 80th anniversary celebration of the Optical Society of America that was held here in Rochester last fall. When I got my tickets for a recent trip I noticed that my very supportive travel agency was celebrating its 85th anniversary. And locally here the Rochester Museum and Science Center is planning its displays for its 85th birthday (yes, I am a trustee there!) and the Rochester Engineering Society is celebrating its 100th anniversary (yes, I am a past president of that organization). So you can see why I feel surrounded by anniversaries!

There is a great tendency under these circumstances to look backwards and get nostalgic. It is often said that those of us who are now classed as senior citizens dwell on the history of our field because we have nothing to look forward to! Nothing could be further from the truth. We are who we are because of the paths we have trod; the future is certainly built on the accomplishments of the past and future acquisition of knowledge is based on a full understanding of current knowledge. So look back with pleasure at past accomplishments as you plot the route to future contributions.

In that vein I pulled Volume 5, No. 4, of our journal for April-May 1967, i.e., 30 years ago. The journal at that time was called the SPIE Journal. The contents of that issue were as follows.

\section{CONTENTS}

USE OF THE ISODENSITRACER FOR
PICTORIAL DATA
$\quad$ Carlton S. Miller
SUPER ELLIPTICAL ZONE PLATES
$\quad$ Gary S. Waldman, Kenneth I. Clifford
CRITICAL PARAMETERS AND METRIC PER-
FORMANCE OF IMAGE ORTHICON TUBES
$\quad$ Walter E. Woehl
SPATIAL FREQUENCY RESPONSE OF
FLYING-SPOT-SCANNER SYSTEMS
$\quad$ Carl F. Shelton
DEPARTMENTS
$\quad$ Physical Optics Notebook - Article 14
$\quad$ Abstracts \& Translations
$\quad$ Engineering Report
Photo-Optics Notebook
COVER STORY - See Article on Page 139

There are four papers; the first, by my former colleague Carlton Miller, was a paper from the 11th SPIE Technical Symposium held in St. Louis, Missouri, in August 1966. The third and fourth papers were also generated from papers at that same symposium. Article number 16 in the celebrated Photo-Optics Note Book entitled "Optical Formulary" was contained in this issue. Many of us thank Herman Shepler for that series. It was in fact the success of that series that prompted George Parent and me to prepare the Physical Optics Notebook. This 1967 issue of the journal contained Article 14, "Coherent Imaging-Resolution." Finally, in the real nostalgia department, the inside back cover is a full-page announcement of a Seminar-in-Depth on Laser Range Instrumenta- 
tion to be held at the Hilton Inn, El Paso, Texas, on 16-17 October 1967. This meeting was the responsibility of the SPIE White Sands Chapter.

Well, that's enough of the nostalgia! Onwards to new endeavors and new discoveries...except for my editor's anecdote.

\section{Editor's Anecdote}

There is a story that my good and long-time colleague Jed Durrenberger likes to tell about me. He was involved in the planning of the El Paso meeting mentioned above. In an airport one day Jed insisted that I must participate in the meeting and that furthermore he needed my title and abstract at the very moment before I took my flight. After some further discussion about topic and coverage, he gave me a pad of paper and a pen and turned around so that I could write my title and 250-word abstract on his back. A few minutes later his "mission was accomplished" and I was committed. Yes, it is a true story! Proof of delivery is given in the proceedings of that conference.

Brian J. Thompson Editor 